УAK 347.73:336.764.1

DOI https://doi.org/10.32837/chc.v0i41.420

Біцюк Анарій Володимирович, аспірант кафедри цивільного права Національного університету "ОАеська юридична академія" ORCID ID: 0000-0002-7443-0420

\title{
ВИЗНАННЯ АКТИВІВ НЕОБҐРУНТОВАНИМИ ЗА НАЯВНОСТІ ФАКТІВ ПРИСВОЄННЯ ДЕРЖАВНИХ АКТИВІВ І ПОВЕРНЕННЯ НЕОБҐРУНТОВАНИХ АКТИВІВ ДО ДЕРЖАВНОГО БЮДЖЕТУ: МІЖНАРОДНИЙ ДОСВІД
}

Постановка проблеми. Початок XXI ст. характеризується Аля нашої країни виходом економіки на новий етап свого розвитку. Висока швиАкість розвитку інформаційних ресурсів призвела Ао формування нової економіки, глобальної за своїми масштабами. Основними ресурсами розвитку Аедалі частіше стають мюди та знання, якими вони володіють, та активи, як матеріальні, так і нематеріальні, однак існують і необгрунтовані активи, якими володіють внасліАок незаконного збагачення при розкраданні державних активів.

Збиток, нанесений розкраданнями, виражається у Аеградації державних установ і пілриві Аовіри Ао них, погіршенні інвестиційного клімату і занепаді систем соціального забезпечення, зокрема систем охорони зАоров'я й освіти.

Розкрадання державних активів - проблема Ауже серйозна. Точну вартість активів, викрадених із країн, що розвиваються, визначити неможливо. Щорічно внаслідок незаконної Аіяльності Аержави втрачають віА 1 Ао 1,6 трлн Аол. [6]. У країнах, які розвиваються, і країнах із перехіАною економікою корумповані чиновники щорічно крадуть Ао 40 млрА Аол. і переводять гроші за корАОн, звіАки їх наАзвичайно важко повернути.

Реальна ціна корупції набагато перевищує номінальну вартість вкрадених активів.

Розкрадання призводять Ао Аеградації державних установ і піАриву Аовіри Ао них (особливо це стосується установ, що працюють у сфері управління державними фінансами та регулювання фінансового сектору); погіршення, якщо не руйнування, інвестиційного кмімату; занепаду системи соціального забезпечення, зокрема системи охорони зАоров'я й освіти, а це особливо негативно позначається на малозабезпечених верствах населення [7].

Стан дослідження теми. Теоретичну основу Аослідження становлять наукові праці таких учених, як Г.О. Винник, В.С. Батиргареєва, В.В. Березнер, С.Я. Бурда, Н.О. Гуторова, А.М. Аемилова, К.П. ЗаАоя, Н.А. Орловська, М.М. Панов, О.С. Пироженко, В.М. Поляков, Г.М. Собко, П.А. Фріс, М.І. Хавронюк та ін.

Метою статті $€$ науковий аналіз загальних положень міжнародного законодавства та законодавства України з метою визначення визнання активів необгрунтованими за наявності фактів присвоєння Аержавних активів і повернення необгрунтованих активів до Аержавного бюАжету, теоретичних і практичних проблем, що виникають у сфері визнання активів необгрунтованими.

Виклад основного матеріалу дослідження 3 повним обґрунтуванням отриманих наукових результатів. 3 огляду на серйозність проблеми та визнаючи необхідність удосконалення механізмів по боротьбі з корупцією та ії наслідками, світове суспільство пропонує систему принципів, покликаних полегшити віАстеження, заморожування, арешт, конфіскацію та повернення необгрунтованих активів, викрадених внаслідок корупції та переміщених Ао інших Аержав. Ці принципи розкриті у Конвенції ООН проти корупції (UNCAC), яка набрала чинності у 2005 р, у розАілі, присвяченому заходам по поверненню активів (в Україні ця конвенція була ратифікована у 2006 р.) [5]. 
Країни, що розвиваються, зіштовхуються із серйозними перешкодами, пов'язаними з відсутністю законодавчої бази Аля конфіскації поза кримінальним провадженням, обмеженими правовими, слідчими та судовими повноваженнями, а також браком ресурсів. Країни, куди виводяться викрадені активи (часто це держави з розвиненою економікою), не завжАи можуть надати юриАичну допомогу постраждалій стороні, оскільки не мають необхідного законодавства, зокрема про конфіскацію активів поза кримінальним проваАженням. У ситуаціях, коли кримінальне розслідування ускладнено через смерть офіційної особи, наявність у неї правового імунітету або в тих випадках, коли ця людина ховається віА правосудАя, процес повернення активів може стати ще більш склаАним.

Конфіскація майна поза кримінальним провадженням - найважливіший інструмент вилучення доходів, отриманих внаслідок корупційних Аій. Цей правовий механізм Аозволяє накласти арешт на викрадені активи, вилучити та конфіскувати їх без винесення обвинувального вироку в рамках кримінального процесу. Він грає важливу роль Аля успішного повернення активів у разі смерті винної особи або в тих випаАках, коли зловмисник знаходиться поза віАповіАною юрисАикцією, володіє правовим імунітетом або наділений настільки великими повноваженнями, що його неможливо піААати кримінальному переслідуванню. У багатьох країнах створені умови Аля конфіскації активів поза кримінальним провадженням, тобто в рамках цивільного процесу. Ухвалення відповідного законодавства рекомендовано на регіональному і міжнародному рівні низкою організацій. Створити механізм Аля конфіскації активів у ситуаціях, коли злочинця не можна підАати кримінальному переслідуванню, закликає також Конвенція ООН проти корупції.

Повернення активів визнається основним принципом Конвенції, і Аержави-учасниці зобов'язуються найтіснішим чином співпрацювати оАин 3 оАним і наАавати ОАин оАному всіляке сприяння в цьому питанні. 3 метою практичної реалізації цього принципу UNCAC передбачає механізми по поверненню незаконно привласнених активів, а також відстеження, заморожування, вилучення, конфіскації та повернення викраденого майна, в т. ч.:

- заходи, покликані забезпечити контроль фінансових установ за підозрілими операціями з особистими банківськими рахунками Аержав- них посадових осіб, членів їхніх сімей і близьких Ао них осіб;

- процеАури, необхіАні Аля того, щоб одна Аержава-учасник мала змогу виступати в судах іншої Аержави-учасниці як приватна особа, що дозволило б їй повернути викрадене майно, захистити власні інтереси в ролі позивача, оскаржити конфіскацію в ролі заявника або виступати як потерпілій у цілях реституції за наказом суду;

- внутрішнє законодавство, яке Аозволило би державі визнати постанову про конфіскацію, винесену судом іншої Аержави, а потім після проведення власного розслідування заморозити та конфіскувати майно, отримане внаслідок корупційної Аіяльності в іншій Аержаві;

- заходи, котрі можуть знадобитися, щоб дозволити конфіскацію майна поза кримінальним проваАженням, особливо в разі смерті або втечі злочинця та ін.

У Конвенції ООН наводяться основні принципи міжнародного співробітництва та розпоряАження активами, конфіскованими однією державою-учасницею за запитом іншої, залежно віА того, яке відношення до цих активів має держава-запитувач.

Особлива увага приділяється розкраданню і віАмиванню незаконно привласнених державних активів: Конвенція зобов'язує Аержаву, що отримала запит, повернути конфісковані активи Аержаві, яка зАійснила запит.

Крім того, UNCAC не тільки закликає кожного учасника розробити внутрішнє законодавство, що забезпечує повернення викрадених державних активів, але і наказує в тих випадках, коли не можна застосувати спеціальне правило, розглядати в першочерговому порядку питання про повернення конфіскованих активів запитуючій Аержаві, попереднім законним власникам або виплату компенсації потерпілим віА злочину. Крім перерахованих вище принципів, Конвенція передбачає, що держава-запитувач може віАрахувати обгрунтовані витрати, понесені в ході розслідування, кримінального переслідування або судового розгляАу, які привели Ао повернення конфіскованих активів або розпорядження ними. Аержави-учасниці можуть також розглянути можливість уклаАання в кожному окремому випаАку Аоговорів або взаємоприйнятних Аомовленостей щОАО Остаточного розпоряАЖення конфіскованими активами.

3 метою сприяння вирішенню проблеми розкрадання державних активів у країнах, що розвиваються, Всесвітній банк разом 3 Управлін- 
ням ООН по наркотикам і злочинності (УНЗ ООН) у вересні 2007 р. запустив програму з повернення викрадених активів (Ініціатива StAR) ${ }^{1}$.

Чільне місце у програмі віАводиться проблемі повернення викрадених активів, а саме: усуненню перешкоА Аля повернення незаконно привласненого майна в найбільших фінансових центрах, створення механізмів, що полегшують повернення активів постраждалим державам, а також заходам, спрямованим проти виведення активів і появи "безпечних зон" Аля корупціонерів.

Повернення державі викрадених активів може Аати приголомшливі результати за умови раціонального витрачання коштів. Навіть частини грошей може вистачити на те, щоб профінансувати життєво важливі соціальні програми або проекти з покращення інфраструктури.

Крім фінансових переваг, програма StAR Аозволить країнам наростити інституційний потенціал, наАасть потужний стримуючий ефект і сприятиме зникненню "безпечних зон” Аля корупціонерів.

В Україні, крім ратифікованої Конвенції ООН проти корупції, питання щодо повернення до держави необґрунтованих активів висвітлені у Законі України «Про Національне агентство України з питань виявлення, розшуку й управління активами, отриманими віА корупційних та інших злочинів" [4]. У ЦПК України цим питанням присвячений розді^ III, зокрема ст. 292 [3]. Вказані законодавчі акти України передбачають процедуру визнання активів необґрунтованими та їх витребування в разі недоведення відповідачем законності набуття майна (цивільну конфіскацію), що є новим Аля національного права та застосовується в межах цивільної юрисликції.

Аеякі українські вчені пропонують "цивільну конфіскацію" сприймати як спосіб вилучення у засудженої за певний злочин особи у державну власність активів, які не стали предметом конфіскації та спеціальної конфіскації у межах кримінального провадження і щодо яких не Аоведено обґрунтованості їх набуття.

ВідповіАно до ст. 41 Конституції України та ст. 1 Протоколу № 1 Конвенції про захист прав ^юАини й основоположних свобод втручання Аержави у право власності: 1) не повинно бути свавільним; 2) має бути зведеним до мінімально необхідного Аля заАоволення суспільних інтересів обсягу;

Країни "великої двадцятки" заявили про підтримку Ініціативи Країни "великої АваАцятки" заявили про піАтримку Ініціативи
StAR у Аекларації саміту із фінансових ринків і світової економіки (Вашингон, 15 мистопада 2008 р.) Ініціатива StAR також згадується в Аоповіді Міжнародної конференції ООН із подальшої Аіяльності у сфері фінансування розвитку Аля огляду ходу здійснення Монтеррейського консенсусу (Аоха, Катар, 2 грудня 2008 р., п. 20). Міністри фінансів країн "Великої вісімки" також підтримали Ініціативу StAR на засіАанні у Потсдамі (Німеччина, 19 травня 2007 р.).
3) з дотриманням вимог законності та справедливого балансу між засобами та метою втручання.

Аопустимим втручанням у право власності $€$ конфіскація активів, за умови, що вказана цивільна конфіскація застосована за рішенням суду у випалках, обсязі та порялку, встановлених законом (ч. 6 ст. 41 Конституції України). Вимога втручання лише за рішенням суду у законодавстві України щодо цивільної конфіскації Аотримана, аАже вона застосовується на піАставі рішення суду.

Визнання необґрунтованими та вилучення активів має такі процесуальні особливості: 1) позов пред'являє прокурор в інтересах держави; 2) відповідачем може бути мише особа, уповноважена на виконання функцій держави або місцевого самоврядування (п. 1 ч. 1 ст. 3 Закону України «Про запобігання корупції»), щодо якої вступив у законну силу обвинувальний вирок суду за вчинення корупційного злочину (переАбаченого у ст. 191, 262, 308, 312, 313, 320, 357,410 , у разі вчинення шляхом зловживання службовим становищем, та у ст. 210, 354, 364, 364-1, 365-2, 368-369-2 КК України) або мегамізацію (відмивання) доходів, одержаних злочинним шляхом.

у разі преА'явлення позову до такої особи прокурор вживає заходів щодо встановлення активів, стосовно яких існують Аокази того, що вони отримані особою необґрунтовано. Оскільки позов має на меті припинення права власності, належним відповідачем завжди є власник активів, а особа, яка має право користування чи розпорядження активами, може залучатися співвідповідачем чи третьою особою, що не заявляє самостійних вимог щодо предмета позову, на боці вілповідача. Крім того, виникає питання щодо необхідності захисту прав добросовісних набувачів активів, якими розпорядився відповідач, що законодавчо не врегульовано у ст. 290-292 цПК України.

Особливістю нормативного врегулювання цивільної конфіскації $€$ те, що у процесуальній нормі закріплена презумпція необґрунтованості активів: "суд визнає необґрунтованими активи, якщо на підставі поданих Аоказів не встановлено, що активи або грошові кошти, необхінні Аля придбання активів, щодо яких поданий позов про визнання їх необґрунтованими, були набуті на законній підставі" [8].

Висновки з дослідження та перспективи подальших розвідок у цьому напрямі. Отже, визнання активів необґрунтованими та їх повернення до бюджету $€$ новим Аля нашої країни. 
Цивільна конфіскація, у т. ч. за відсутності обвинува^ьного вироку, відповідає міжнародним правовим стандартам.

3 метою зменшення проявів корупції в Україні законодавець з урахуванням міжнародного Аосвіду став на шлях створення правового базису протидії цьому негативному суспільному явищу в частині визнання активів необґрунтованими та повернення їх до державного бюджету, проте зазначені вище питання потребують наукового АосліАження, що налалі Аозволить піА час прийняття віАповіАних рішень за наявності прилюАного обговорення важливих законопроектів враховувати Аумки практиків-юристів і науковців, а це призведе Ао високого рівня нормотворчої Аіяльності.

\section{AITEPATYPA:}

1. Конституція України : Закон України від 28 червня 1996 р. Відомості Верховної Ради. 1996. № 30. Ст. 141.

2. Цивільний Кодекс України : Закон України від 16 січня 2003 р. № 40-44. URL: https://zakon.rada.gov.ua/laws/show/435-15 (дата звернення: 28.09.2020).

3. Цивільний процесуальний кодекс України. Вiдомості Верховної Ради Украӥни. 2004. № 40-41, 42. Cт. 492. URL: https:// zakon.rada.gov.ua/laws/show/1618-15 (дата звернення: 22.09.2020).

4. Про Національне агентство України з питань виявлення, розшуку та управління активами, одержаними від корупційних та інших злочинів : Закон України. Відомості Верховної Ради. 2016. № 1. Ст. 2. URL: https://zakon.rada.gov.ua/laws/ show/772-19\#Text (дата звернення: 30.09.2020).

5. Конвенція Організації Об’єднаних Націй проти корупції. Відомості Верховної Ради України. 2007. № 49. URL: https:// zakon.rada.gov.ua/laws/show/995_c16\#Text (дата звернення: 28.09.2020).

6. UNODC and The World Bank, "Stolen Asset Recovery (StAR) Initiative: Challenges, Opportunities, and Action Plan" (World Bank, Washington, DC, 2007), p. 10, citing Raymond Baker, Capitalism's Achilles Heel: Dirty Money and How to Renew the FreeMarket System (Hoboken, NJ: John Wiley \& Sons, Inc., 2005).

7. Доклад про Ініціативу StAR. C. 8. UR1: https://www.unodc.org/unodc/ru/frontpage/2013/February/the-star-initiative-steppingup-a-gear.html (дата звернення: 28.09.2020).

8. Х Хавронюк М. Спецконфіскація - покарання без вироку суду або покарання без злочину. Paкурс. 2016. URL: http://ua.racurs. ua/1385-sprobazaprovadjennya-speckonfiskaciyi.

\section{Біцюк Андрій Володимирович \\ ВИЗНАННЯ АКТИВІВ НЕОБҐРУНТОВАНИМИ ЗА НАЯВНОСТІ ФАКТІВ ПРИСВОЄННЯ АЕРЖАВНИХ АКТИВІВ I ПОВЕРНЕННЯ НЕОБҐРУНТОВАНИХ АКТИВІВ АО АЕРЖАВНОГО БЮАЖЕТУ: МІЖНАРОАНИЙ АОСВІА}

Початок XXI ст. характеризується Аля нашої країни виходом економіки на новий етап свого розвитку. Висока швилкість розвитку інформаційних ресурсів призвела Ао формування нової економіки, глобальної за своїми масштабами. Основними ресурсами розвитку дедалі частіше стають ^юди і знання, якими вони володіють, та активи, як матеріальні, так і нематеріальні, причому існують і необгрунтовані активи, якими володіють внаслідок незаконного збагачення при розкраданні державних активів.

Збиток, нанесений розкраданнями, тобто присвоєння необґрунтованих активів, виражається у деградації державних установ і підриві довіри до них, погіршенні інвестиційного клімату і занепаді систем соціального забезпечення, зокрема систем охорони здоров'я й освіти.

Присвоєння необгрунтованих активів - проблема дуже серйозна. У країнах, що розвиваються, і країнах із перехідною економікою корумповані чиновники щорічно присвоюють до 40 млрА Аол. як необґрунтовані активи та переводять гроші за корАон, звідки їх надзвичайно важко повернути. Реальна ціна корупції набагато перевищує номінальну вартість вкрадених активів.

Розкрадання призводять до Аеградації державних установ і підриву довіри до них (особливо це стосується установ, які працюють у сфері управління державними фінансами та регулювання фінансового сектору); погіршення, якщо не руйнування, інвестиційного клімату; занепаду системи соціального забезпечення, зокрема системи охорони зАоров'я й освіти, що особливо негативно позначається на малозабезпечених верствах населення.

3 огляду на серйозність проблеми та визнаючи необхідність удосконалення механізмів по боротьбі 3 корупцією та ії наслідками, світове суспільство пропонує систему принципів, покликаних полегшити віАстеження, заморожування, арешт, конфіскацію та повернення необґрунтованих активів, викрадених внаслідок корупції та переміщених до інших держав.

Ключові слова: активи, корупція, необгрунтовані активи, Аержавні активи, цивільна конфіскація, легалізація Аоходів, віАстеження, заморожування, арешт, конфіскація.

\footnotetext{
Bitsiuk Andrii

RECOGNITION OF ASSETS AS UNFOUNDED IN THE PRESENCE OF FACTS OF MISAPPROPRIATION OF STATE ASSETS AND RETURN OF UNJUSTIFIED ASSETS TO THE STATE BUDGET. INTERNATIONAL EXPERIENCE

The beginning of the XXI century is characterized for our country by the entry of the economy into a new stage of its development. The high speed of development of information resources has led to the formation of a new economy, global in scale. The main resources for development are increasingly people and the knowledge they possess, and
} 
assets, both tangible and intangible. At the same time, there are unjustified assets that are owned as a result of illegal enrichment in the theft of state assets.

The damage caused by embezzlement, ie the misappropriation of unjustified assets, is expressed in the degradation of public institutions and the undermining of trust in them, the deterioration of the investment climate and the decline of social security systems, including health care and education.

The misappropriation of unjustified assets is a very serious problem. In developing countries and countries with economies in transition, corrupt officials misappropriate up to $\$ 40$ billion annually. as unreasonable assets and transfer money abroad, from where it is extremely difficult to return. The real cost of corruption far exceeds the face value of stolen assets.

Theft leads to the degradation of public institutions and the undermining of trust in them (especially in the field of public finance management and financial sector regulation); deterioration, if not destruction, of the investment climate; the decline of the social security system, in particular the health care and education systems, which has a particularly negative impact on the poor.

Given the seriousness of the problem and recognizing the need to improve mechanisms to combat corruption and its consequences, the world community proposes a system of principles designed to facilitate the tracing, freezing, arrest, confiscation and return of unjustified assets stolen as a result of corruption and relocated.

Key words: assets, corruption, unjustified assets, state assets, civil confiscation, money laundering, tracking, freezing, arrest, confiscation. 